\title{
Comparison of Sub-Provincial Cities Competitiveness in China Based On PCA Method
}

\author{
Han Yingjun, Wang Xiaoyang,Han Jiwei \\ (the Hebei United University,063009)
}

\begin{abstract}
Based on PCA method, this paper sets an evaluation indicator system which is used to evaluate the sub-provincial cities' competitiveness. By ranking the overall competitiveness and integrating with the analysis of growth index calculation for competitiveness, the paper studies on science, technology and economic competitiveness and development of the 15 vice-provincial cities from 2006 to 2010. This paper provides references for decision-makers to promote a city's competitiveness and to strengthen the role of science and technology in support of economic transformation and upgrading, and to further push on the construction of innovative city.
\end{abstract}

Keywords: Sub-Provincial cities, competitiveness, PCA method

\section{Introduction}

By the end of 2005,China had661cities, 42.99\% of the total population of the city. Only287prefecture-level or above cities, which accounted for59.9 percent of the national GDP, of which15sub-provincial cities, the total population and GDP accounts for $27.1 \%$ and $33.8 \%$ of the total urban population and GDP, respectively, and these cities have become the region's growth pole of a strategicanchorand economic development.

The study on city competitive ability has become a hot subject, as it is important to the development of cities and the local area. 15sub-provincialcities such as Guangzhou are under levels of four large municipalities, the urban management system is similar and the cities are regional innovation center with the level of economic and technological development, its technological competitiveness has been widespread concern. However, the research on perspective of competitiveness developments and changes and technological economic coordination are rare. By constructing an evaluation system for competitiveness, using 2006-2010datafor analysis of scientific and technological competitiveness in 15sub-provincialcities, and comprehensive competitiveness is also analyzed. By introducing technological competitiveness growth index, the technological competitiveness improvement degree in 15 cities is studied. Through the coordination analysis of scientific and technological and economic competitivenessof15cities, we make a cluster analysis.

\section{Indicator system setting}

To introduce the comprehensive competitiveness of sub-provincial cities, we first introduce the indicator system setting of science and technology competitiveness, because science and technology competitiveness is one of the most significant indicator of the comprehensive competitiveness, so the part is very important.

According to related evaluation system, from four aspects as science and technology investment levels, technological output level, technology and economic and social development degree as well as scientific and technological potential to build a more complete technology competition force comprehensive evaluation system (see Table 1). 
Table 1 Sub-provincial city technology competitiveness evaluation index system

\begin{tabular}{|c|c|c|c|c|c|c|}
\hline First level index & Weights & Second index & Weights & Third level index & Weights & Total weights \\
\hline \multirow{8}{*}{$\begin{array}{l}\text { Science and } \\
\text { technology } \\
\text { investment }\end{array}$} & \multirow{8}{*}{0.3} & \multirow{4}{*}{$\begin{array}{l}\text { Financial } \\
\text { investment } \\
\text { in science } \\
\text { and } \\
\text { technology }\end{array}$} & \multirow{4}{*}{0.5} & R\&D total expenditure & 0.3 & 0.045 \\
\hline & & & & R\&D expenditure share of GDP & 0.3 & 0.045 \\
\hline & & & & Local Financial Expenditure & 0.2 & 0. 03 \\
\hline & & & & The proportion of local fiscal expenditure & 0.2 & 0.03 \\
\hline & & \multirow{4}{*}{$\begin{array}{l}\text { Science and } \\
\text { technology } \\
\text { manpower }\end{array}$} & \multirow{4}{*}{0.5} & Total professional and technical personnel & 0.3 & 0.045 \\
\hline & & & & The number personnel per million people & 0.3 & 0.045 \\
\hline & & & & R\&D activities staff & 0.2 & 0.03 \\
\hline & & & & Proportion of employees for R\&D personnel & 0.2 & 0.03 \\
\hline \multirow{8}{*}{ Scientific output } & \multirow{8}{*}{0.4} & \multirow{4}{*}{$\begin{array}{l}\text { Patent } \\
\text { output }\end{array}$} & \multirow{4}{*}{0.5} & Patents granted & 0.2 & 0.04 \\
\hline & & & & Patents granted per 100,000 people & 0.2 & 0.04 \\
\hline & & & & Invention patents granted & 0.3 & 0.06 \\
\hline & & & & Per 100,000 patents granted & 0.3 & 0.06 \\
\hline & & \multirow{4}{*}{$\begin{array}{l}\text { Technolog } \\
\text { industry } \\
\text { output }\end{array}$} & \multirow{4}{*}{0.5} & High-tech industry output & 0.25 & 0.05 \\
\hline & & & & High-tech industries proportion & 0.25 & 0.05 \\
\hline & & & & High-tech product exports & 0.25 & 0.05 \\
\hline & & & & High-tech products exports proportion & 0.25 & 0.05 \\
\hline \multirow{4}{*}{$\begin{array}{l}\text { Coordination degree } \\
\text { of technology, } \\
\text { economic and social } \\
\text { development }\end{array}$} & \multirow{4}{*}{ 0. 15} & \multirow{2}{*}{$\begin{array}{l}\text { Economic } \\
\text { growth }\end{array}$} & \multirow{2}{*}{0.4} & Per capita GDP & 0.5 & 0.03 \\
\hline & & & & Gross Domestic Product (GDP) & 0.5 & 0.03 \\
\hline & & \multirow{2}{*}{$\begin{array}{l}\text { Environment| } \\
\text { resources }\end{array}$} & \multirow{2}{*}{10.6} & Wastewater discharge compliance rate & 0.5 & 0.0405 \\
\hline & & & & Ten thousand GDP comprehensive energy & 0.5 & 0.0495 \\
\hline \multirow{5}{*}{$\begin{array}{l}\text { Scientific and } \\
\text { technological } \\
\text { potential }\end{array}$} & \multirow{5}{*}{0.15} & \multirow{3}{*}{$\begin{array}{l}\text { Higher } \\
\text { base }\end{array}$} & \multirow{3}{*}{0.6} & Number of students in colleges & 0.3 & 0.027 \\
\hline & & & & Local fiscal expenditure on education & 0.35 & 0.0315 \\
\hline & & & & Local fiscal expenditure proportion & 0.35 & 0.0315 \\
\hline & & \multirow{2}{*}{$\begin{array}{l}\text { Information } \\
\text { level }\end{array}$} & \multirow{2}{*}{0.4} & Internet users & 0.5 & 0.03 \\
\hline & & & & Million Internet users & 0.5 & 0.03 \\
\hline
\end{tabular}

\section{Index system evaluation of science and technology competitiveness}

Using principal component analysis, the available five basic factors reflect most of the information of 25variables(three targets). Five factor sare: the total amount of techno-economic factors, the degree of technology investment factor, scientific and technological potential factors, educational factors and harmonious development factor. We can obtain the technological competitiveness estimates from 2006-2010of15cities, see Table 2. 
Table 2 Sub-provincial cities technological competitiveness ranking from2006-2010

\begin{tabular}{|c|c|c|c|c|c|}
\hline Rank & Year 2006 & Year 2007 & Year 2008 & Year 2009 & Year 2010 \\
\hline 1 & Shenzhen & Shenzhen & Shenzhen & Shenzhen & Shenzhen \\
\hline 2 & Guangzhou & Guangzhou & Guangzhou & Guangzhou & Guangzhou \\
\hline 3 & Wuhan & Hangzhou & Hangzhou & Hangzhou & Hangzhou \\
\hline 4 & Nanjing & Nanjing & Ningbo & Nanjing & Nanjing \\
\hline 5 & Hangzhou & Dalian & Nanjing & Ningbo & Ningbo \\
\hline 6 & Shenyang & Wuhan & Qingdao & Wuhan & Chengdu \\
\hline 7 & Xi'an & Ningbo & Chengdu & Chengdu & Wuhan \\
\hline 8 & Qingdao & Qingdao & Shenyang & Xi'an & Qingdao \\
\hline 9 & Chengdu & Shenyang & Wuhan & Shenyang & Dalian \\
\hline 10 & Xiamen & Chengdu & Dalian & Qingdao & Xi'an \\
\hline 11 & Ningbo & Xi'an & Ji'nan & Dalian & Shenyang \\
\hline 12 & Jinan & Harbin & Xiamen & Harbin & Harbin \\
\hline 13 & Harbin & Ji'nan & Xi'an & Ji'nan & Xiamen \\
\hline 14 & Dalian & Xiamen & Changchun & Xiamen & Ji'nan \\
\hline 15 & Changchun & Changchun & Harbin & Changchun & Changchun \\
\hline
\end{tabular}

(1) Guangzhou, Shenzhen have obviously competitive advantages in science and technology. From 2006-2010, Shenzhen and Guangzhou ranked the first and second place in sub-provincial cities.

(2) The level of innovation and technology incremental capacity is the most significant in Hangzhou, rising from No. 5in 2006to the third in four years of 2007,2008,2009,2010, above Wuhan, Nanjing and had a good development trend.

(3) From year 2006-2010, Nanjing was ranking the topfourin15cities, which displays a strong scientific and technological innovation capacity.

(4) Ningbo momentum is among the strongest in 15cities. Although in 2006, it lived in the $11^{\text {th }}$ of 15 cities, in 2007thatrose to No. 7, 2008 the first fourth rank, living behind Shenzhen, Guangzhou, Hangzhou and over Nanjing and held in the fifth in 2009 and 2010.

(5) Chengdu increased rapidly. Although once from nine in 2006 fell to10in 2007, but2008, 2009, it was uptotheposition 7, 7, 6, respectively.

(6) In recent years, the competitiveness of Wuhan continued to decline. Wuhan has many universities, so it has good industrial base and scientific and technological potential, but the human and financial investment in science and technology is inadequate, institutional mechanisms innovation is weak, science and technology advantage did not translate into competitive advantage.

(7) Qingdao and Dalian have similar resource endowments, they both have excellent harbor and good industrial base, technological competitiveness was generally favorable during2006-2010, which moved up slightly.

(8) Shenyang and Xi'an was down from the sixth and seventh place all the way, respectively,totheposition9, 11, and 8, 13placein 2008 and so on. Although there are many colleges and universities, which has good heavy industry base, but institutional innovation and technological innovation has short comings.

(9) Changchun' technological innovation was ranking behind, the situation has not been improved continuously. The competitiveness in Jinan, Xiamen, 
Harbin, and several other cities are also relatively weak.

\section{Index system evaluation of comprehensive competitiveness}

According to the city's comprehensive competitiveness, follow the indicators selected principles of scientific, purpose, operability and comparability, we select the comprehensive economic strength, the strength of the exchange, scientific and technological innovation strength and social environment overall strength to build cities comprehensive competitiveness index system.

Table 3 Comprehensive competitiveness comparison of 15 sub-provincial cities

\begin{tabular}{|c|c|c|c|c|c|c|c|c|c|c|c|}
\hline City & $\begin{array}{l}\text { Comprehensive } \\
\text { economic } \\
\text { strength }\end{array}$ & $\begin{array}{l}\text { Exchange } \\
\text { strength }\end{array}$ & $\begin{array}{l}\text { Scientific and } \\
\text { technological s } \\
\text { strength }\end{array}$ & $\begin{array}{l}\text { Comprehensive } \\
\text { social environment } \\
\text { strength }\end{array}$ & $\begin{array}{l}\text { Comprehensive } \\
\text { competitiveness }\end{array}$ & s City & $\begin{array}{l}\text { Comprehensive } \\
\text { economic } \\
\text { strength }\end{array}$ & $\begin{array}{l}\text { Exchange } \\
\text { strength }\end{array}$ & $\begin{array}{l}\text { Scientific and } \\
\text { technological } \\
\text { strength }\end{array}$ & $\begin{array}{l}\text { Comprehensive } \\
\text { social environment } \\
\text { strength }\end{array}$ & $\begin{array}{l}\text { Comprehensive } \\
\text { competitiveness }\end{array}$ \\
\hline Dalian & $1.847(9)$ & $0.708(5)$ & $0.6431(3)$ & $2.806(7)$ & $1.558(9)$ & Qingdao & $1.824(10)$ & $0.560(7)$ & $0.317(14)$ & $2.754(8)$ & $1.427(12)$ \\
\hline Changchun & $1.858(8)$ & $0.204(14)$ & $1.167(9)$ & $2.461(12)$ & $1.505(10)$ & Wuhan & $2.262(4)$ & $0.543(9)$ & $1.246(7)$ & $1.417(14)$ & $1.453(11)$ \\
\hline Harbin & $1.621(14)$ & $0.189(15)$ & $1.036(11)$ & $2.188(13)$ & $1.330(14)$ & Guangzhou & $4.372(2)$ & $1.355(2)$ & $1.626(4)$ & $3.416(2)$ & $2.843(2)$ \\
\hline Nanjing & $1.949(6)$ & $0.569(6)$ & $2.478(1)$ & $3.239(3)$ & $2.128(4)$ & Shenzhen & $7.678(1)$ & $2.121(1)$ & $1.966(2)$ & $8.884(1)$ & $5.440(1)$ \\
\hline Hangzhou & $1.803(12)$ & $0.527(11)$ & $1.553(5)$ & $3.096(4)$ & $1.809(6)$ & Chengdu & $1.819(11)$ & $1.035(3)$ & $1.285(8)$ & $2.988(5)$ & $1.821(5)$ \\
\hline Ningbo & $1.117(15)$ & $0.532(10)$ & $0.209(15)$ & $2.510(10)$ & $1.121(15)$ & Xi'an & $2.018(5)$ & $0.333(12)$ & $1.493(6)$ & $1.195(15)$ & $1.344(13)$ \\
\hline Xiamen & $3.703(3)$ & $0.980(4)$ & $0.904(12)$ & $2.645(9)$ & $2.194(3)$ & $\begin{array}{l}\text { Standard } \\
\text { deviation }\end{array}$ & 1.653 & 0.507 & 0.634 & 1.738 & 1.055 \\
\hline
\end{tabular}

Taking into account the comparability between different cities, all of these indicators adopt per capital or relative proportion. Then, the comprehensive competitiveness comparison of 15 sub-provincial cities can be seen in Table 3. The number in parentheses represents city's comprehensive competitiveness sort order for each component.

From the comparison of scores on the table and results of each city's comprehensive competitiveness and competitive breakdown, we can draw the following conclusions: First, from the city's comprehensive competitiveness score, the comprehensive competitiveness in 15 sub-provincial cities in China's is strong as a whole, its lowest score is above 1.0, while their score difference is not very significant, and the standard deviation of the city's comprehensive competitiveness is 1.055. Second, from the view of the city's comprehensive economic competitiveness, the over all economic competitiveness gap of15sub-provincialcitiesis more significant, the standard deviation has reached1.655. Third, from the open exchange competitiveness, the score difference in 15 sub-provincial city is not great, the standard deviation is only 0.507 . Fourth, from the point view of technological innovation competitiveness, the technological innovation competitiveness gap of 15 cities is not very obvious, their standard deviation is only 0.634 . From the overall competitiveness of the social environment, this score difference in 15 cities is very significant and their standard deviation is 1.738 .

\section{Conclusions}

Considering the regional characteristics of different cities, the economic structure, technological level is quite different, but the comprehensive competitiveness in different cities is close linked to the science and technology development, social environmental factors and the industrial competitiveness. The more developed the general economy, its technological competitiveness is relatively high, the competitiveness is also high, and vice versa. The growth index higher, the urban and technological competitiveness stronger in sub-provincial cities. How to start and promote comprehensive development of a relatively weak competitiveness of the city still needs further study.

Many cities are rich in scientific and educational resources, have good science and technology strength 
and a good industrial base. There is a need to streng then the cultivation and development of market economy and streng then combination to ensure the scientific and technological potential in to a technological competitive edge to strengthen the competitiveness in other cities. While focusing on export-oriented investment in coastal cities, we must also strengthen the independent innovation cap a city building of local industries to promote competitiveness and promote sustainable development.

\section{References}

[1] National Science and Technology Progressive Statistical Monitoring and Evaluation Task Force. National Science and Technology Progress Statistical Monitoring Report 2010 [R]. Beijing, 2010.

[2] Study Research Group of China Science and Technology Development. China Technology Development Report
2000 [M]. Beijing: Social Sciences Academic Press, 2000.

[3] Liu C, Wang F, et al. Robust $\mathrm{H} \infty$ Control for Satellite Attitude Control System with Uncertainties and Additive Perturbation[J]. International Journal of Science, 2014, 1(2):1-9.

[4] Xu J. Governing city-regions in China: Theoretical issues and perspectives for regional strategic planning $[\mathrm{J}]$. Town Planning Review, 2008, 79(2): 157-186.

[5] Liu C, et al. Research on Trends and Key Technologies of Small Satellites [J]. International Journal of Science, 2014, 1(2): $38-42$.

[6] Chen Z. Comprehensive Competitiveness Evaluation and Comparison in Sub-provincial cities in China[J]. Commercial Research, 2007(6): 13-17. 